\title{
Cohort profile: the Nigerian HIV geriatric cohort study
}

\author{
Patrick Dakum', Yohanna Kambai Avong', Michael Kolawole Odutola', James Okuma', \\ Gbenga Ayodele Kayode ${ }^{1^{*}}$ (D), Iboro Ekpo Nta', Nicaise Ndembi', Charles Mensah'1, Hadiza Khamofu², \\ Prosper Okonkwo ${ }^{3}$, John Oko Okpanachi ${ }^{4}$ and Echezona Ezeanolue ${ }^{5,6}$
}

\begin{abstract}
Background: The Nigerian HIV Geriatric Cohort (NHGC) is a longitudinal cohort setup to learn how elderly people living with HIV (EPLHIV) in Nigeria fare, despite not being prioritized by the national treatment program, and to deepen knowledge for their differentiated care and achieve better outcomes. In this paper, we describe data collected on sociodemographic and clinical data from EPLHIV from the inception of Nigeria's national HIV program to 2018.
\end{abstract}

Methods: Patient-level data spanning the period 2004 to 2018, obtained from comprehensive HIV treatment hospitals, that are supported by four major PEPFAR-implementing partners in Nigeria were used. These 4 entities collaborated as member organizations of the Nigeria Implementation Science Alliance. We defined elderly as those aged 50 years and above. From deidentified treatment records, demographic and clinical data of EPLHIV $\geq 50$-yearold at ART initiation during the review period was extracted, merged into a single REDcap ${ }^{\oplus}$ database, and described using STATA 13.

Results: A total of 101,652 EPLHIV were analysed. Women accounted for 53,608 (53\%), 51,037 (71\%) of EPLHIV identified as married and 33,446 (51\%) unemployed. Median age was 57.1 years (IQR 52-60 years) with a median duration on ART treatment of 4.1 years (IQR 1.7-7.1 years). ART profile showed that 97,586 (96\%) were on 1st-line and 66,125 (65\%) were on TDF-based regimens. Median body mass index (BMI) was $22.2 \mathrm{~kg} / \mathrm{m}^{2}$ (IQR 19.5-25.4 kg/ $\mathrm{m}^{2}$ ) with 43,012 (55\%), 15,081 (19\%) and 6803 (9\%) showing normal (BMl $18.5-<25 \mathrm{~kg} / \mathrm{m}^{2}$ ), overweight (BMl 25 $<30 \mathrm{~kg} / \mathrm{m}^{2}$ ) and obese $\left(\mathrm{BMI} \geq 30 \mathrm{~kg} / \mathrm{m}^{2}\right.$ ) ranges respectively. Prevalence of hypertension (systolic-BP $>140 \mathrm{mmHg}$ or

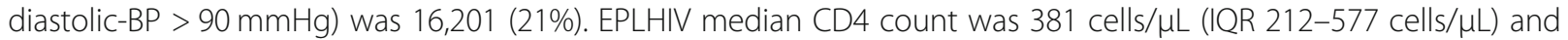
26,687 (82\%) had a viral load result showing < 1000copies/ml within one year of their last visit. As for outcomes at their last visit, 62,821 (62\%) were on active-in-treatment, 28,463 (28\%) were lost-to-follow-up, 6912 (7\%) died and $2456(3 \%)$ had stopped or transferred out. Poor population death records and aversion to autopsies makes it almost impossible to estimate AIDS-related deaths.

Conclusions: This cohort describes the clinical and non-clinical profile of EPLHIV in Nigeria. We are following up the cohort to design and implement intervention programs, develop prognostic models to achieve better care outcomes for EPLHIV. This cohort would provide vital information for stakeholders in HIV prevention, care and treatment to understand the characteristics of EPLHIV.

Keywords: Elderly, Geriatric, HIV/AIDS, Nigeria

\footnotetext{
* Correspondence: gakayode@yahoo.co.uk

${ }^{1}$ Institute of Human Virology, Abuja, Nigeria

Full list of author information is available at the end of the article
}

(c) The Author(s). 2020 Open Access This article is licensed under a Creative Commons Attribution 4.0 International License, which permits use, sharing, adaptation, distribution and reproduction in any medium or format, as long as you give appropriate credit to the original author(s) and the source, provide a link to the Creative Commons licence, and indicate if changes were made. The images or other third party material in this article are included in the article's Creative Commons licence, unless indicated otherwise in a credit line to the material. If material is not included in the article's Creative Commons licence and your intended use is not permitted by statutory regulation or exceeds the permitted use, you will need to obtain permission directly from the copyright holder. To view a copy of this licence, visit http://creativecommons.org/licenses/by/4.0/. The Creative Commons Public Domain Dedication waiver (http://creativecommons.org/publicdomain/zero/1.0/) applies to the data made available in this article, unless otherwise stated in a credit line to the data. 


\section{Why was the cohort set up?}

Older adults living with the human immunodeficiency virus (HIV) are set to multiply worldwide [1-3]. HIV/ AIDS is a major public health problem among older adults, approximately 6 million people over the age of 50 years are living with HIV worldwide [4]. In subSaharan Africa, approximately 3 million people older than 50 years of age, are HIV-infected, which represents an average of $14 \%$ of affected adults and $11 \%$ of adults on antiretroviral therapy (ART) [5, 6]. In Nigeria, a cross-sectional study at one of the largest treatment centres, reported that $10 \%$ of the studied population were aged, 51 to 60 years, while $0.6 \%$ were $>60$ years [7]. At the national level, $54 \%$ of the 3.4 million people that were living with HIV in 2012 were between 15 to 64 years [8]. The recently concluded 2018 Nigeria HIV/ AIDS Indicator and Impact Survey (NAIIS), a household-based survey that assessed the prevalence of HIV and related health indicators in household members aged 0-64 years old, found the distribution of HIV burden across those aged 50 years and above at $13 \%$, which is approximately 280,000 based on new total estimates of 1.9 million persons living with HIV in Nigeria [9]. Based on the NAIIS, gender disaggregation statistics showed that prevalence was highest among females aged $35-39$ years at $3.3 \%$, and the highest among males age $50-54$ years at $2.3 \%$. This pool will grow significantly as many ART patients are expected to cross the 50-years baseline, given the efficacy of ART and the current global drive to expand access to treatment and end HIV/ AIDS by 2030 [10].

Information on the geriatric population living with HIV in Nigeria is sparse and a systematic description of the HIV geriatric cohort is required to change this. The early and widely recognized impact of AIDS on the elderly was the phenomenon of AIDS orphans- children who lost at least a parent as a result of HIV-related mortality. The report Children on the Brink: 2002 indicates that in 2001, there were 38 million orphans in Africa, 11 million of whom were attributable to AIDS mortality [11]. It predicted that in 2010, 42 million orphans will be in Africa, 20 million of whom will be the result of AIDS mortality. Since formal social security systems do not exist in most sub-Saharan African countries, the elderly largely bear the burden of taking care of the orphans, which compromises their health [12].

HIV-infection and attendant antiretroviral (ARV) treatment complicate elderly health. AIDS has a disproportionate impact on the health of the elderly compared with the younger adults [13]. Opportunistic infections (OIs) such as pneumocystis pneumonia, extrapulmonary tuberculosis, and candidiasis have been reported in the elderly [13]. Both HIV and aging synergistically decrease function of $\mathrm{B}$ and $\mathrm{T}$-cell lymphocytes which compromises the host's immunity leading to more OIs. Also, HIV-infection independently creates metabolic abnormalities $[14,15]$ and the toxicities of ARVs and certain drugs used for OIs, create a wide range of diseases including, type 2 diabetes mellitus, myocardial infarction (MI) and atherosclerotic cardiovascular disease [16, 17]. In 2016, a Médecins Sans Frontières (MSF) multi-national study reported a higher risk of death among HIV infected people who were aged 50 years and above [16]. Furthermore, age is a risk factor for cardiometabolic disorders thus, older adults are likely to bear a dual burden of HIV and cardio-metabolic abnormalities [18], which is on the rise in sub-Saharan Africa.

Nigeria's HIV-infected elderly face significant challenges due to age, inadequate health care, low social security and a dwindling economy. Although this context necessitates a concerted focus on the elderly, there is no structured care for them. Several reasons contribute to this; earlier studies projected HIV/AIDS prevalence and transmission as a youth issue [2], this has inadvertently omitted elderly-care in the HIV-control program design. Being elderly is associated with sustaining risky behaviour like less condom use, higher preference for multiple sexual partners [19] and wife inheritance [20], which predisposes to new infections [21,22].

It is therefore critical to establish a HIV geriatric cohort in Nigeria to provide evidence to add life to years [23], improve quality of life and outcomes of older adults living with HIV. In this paper, we describe socio demographic and clinical data from older HIV positive clients from the inception of Nigeria's national HIV program, and we plan to longitudinally study this cohort with the aim of designing and implementing intervention programs that would improve better health outcomes.

\section{Which cohorts contribute to the collaboration?}

The treatment and prevention of HIV/AIDS in Nigeria is coordinated by the National Agency for the Control of AIDS (NACA) - an agency of the Federal Ministry of Health (FMOH). The United States of America's Government (USG) since 2006, through its Presidents Emergency Plan for AIDS Relief (PEPFAR), supported Nigeria's free access ART program. Four major implementing partners (IPs) directly cover the treatment program across all of Nigeria's six geopolitical regions in partnership with health facilities under the general supervision of the US agencies and NACA.

These IPs provide technical support for HIV treatment in most Nigerian states, they include: the Institute of Human Virology Nigeria (IHVN) covering the Federal Capital Territory (FCT) and 3 States (Kano, Katsina and Nassarawa); FHI360 covering 12 States (Adamawa, Akwa Ibom, Anambra, Bauchi, Bayelsa, Borno, Cross River, Edo, Jigawa, Lagos, Rivers and Yobe); APIN Public 
Health Initiative in Nigeria (APIN) covering 8 States (Lagos, Ogun, Osun, Ekiti, Ondo, Oyo, Plateau and Benue); and Catholic Caritas Foundation of Nigeria (CCFN G) covering 4 States (Delta, Ebonyi, Enugu and Imo). These IPs use a nationally standardized method of data collection and schedule monthly follow-up visits for their patients. This cohort is the first to be set-up to pool geriatric data from these IPs. Furthermore, to the best of our knowledge, no study has described Nigeria's nationwide geriatric HIV positive population using combined data from these IPs.

\section{Definition of terms \\ Older age}

The statistical cut-off for assessing old age varies. Rather than artificially categorizing life into stages such as middle age or old age, it assumes we age from birth. Nevertheless, for statistical purposes, it is often necessary to divide populations into age groups. World Health Organization (WHO) recommends 60 years and over as a statistical cut-off for older age [23]. However, some analyses refer to populations of different ages such as $\geq 50$ years, $\geq 65$ years or $\geq 80$ years. In this study, we adopted $\geq 50$ years as our cut-off for old age. This assumption is based on Nigeria's population life expectancy from birth (2016) which was 54 years [men (55 years); women (56 years)] [24]. Participants who are $\geq 50$ years at time of testing positive to HIV will be classified as 'older adults', 'elderly' or 'geriatrics'.

\section{WHO stage 3 and 4}

The diseases defined as WHO stage 3 and 4 in this study are presented in Table 2 (pages 28 to 29) of the National Guidelines for HIV Prevention Treatment and Care $(2016,8]$.

\section{Lost to follow-up (LTFU)}

LTFU was defined as $>90$ days late for the next scheduled appointment, with visits scheduled every month. Participants could experience multiple LTFU episodes after returning to care in the interim. We report on LTFU event at the last visit based participants status at their last vist.

\section{Who is in the cohort?}

The study population included all EPLHIV from four major IPs providing treatment services across all of Nigeria's six geopolitical regions. Patient-level socio demographic and clinical data of participants treated at the health facilities supported by the IPs were used. Patients were prospectively enrolled at first contact with a HIVservice facility and are followed-up monthly. We use deidentified data of EPLHIV from the date first tested positive for HIV as contained in the IPs databases between the period 2004-2018. The databases were merged as a single REDcap ${ }^{\circ}$ database and analysed using STATA 13. Ethical clearance for the use of the secondary data was obtained from the IRB board (IRB019-SD) of APIN.

\section{How often is follow up?}

Data are collected during the initial visit (study enrolment) and atleast monthly during follow up. Research health care workers collect epidemiological data using a standardized uniform data collections tools. Detailed contact information (address and phone numbers) are collected from all participants. Follow-up visits are scheduled at appropriate times and reminders are sent by text messages and phone calls. Where participants cannot be reached by phone, home visits are conducted.

\section{What has been measured?}

The data are collected at EPLHIV's clinic visit using national standardized Case Report Forms (CRFs). Data was collected at baseline and scheduled follow-up visits on socio demographic (sex, age, marital status, education, occupation), dates of HIV diagnosis and initiating therapy, AIDS-defining conditions, laboratory data (CD4 cell count, viral load), ART regimen and others to determine HIV comorbidities (blood pressure, body mass index, blood glucose measurements). Trained clinicians obtained this information at each patient's visit. The HIV biomarkers including CD4 cell count done 6-monthly and since 2016 routine viral load done 6 months postinitiation of ARTs for newly identified clients, then yearly for stable patients (those with $\mathrm{VL}<1000$ copies/ $\mathrm{ml}$ ) and more frequently as needed for patients with derailed values. The CRFs are entered into a secure electronic capture database with a study ID used as a unique patient identifier. Data was cleaned and stored in a central geriatric database. In the analysis, we report baseline characteristics, treatment and clinical outcomes as percentages for categorical data and medians (interquantile ranges) for continuous data.

Participants were considered on ART at baseline if they initiated before or within 30 days of enrolment. CD4 count, BMI, weight, WHO stage and blood pressure (BP) were those measurements closest to enrolment, provided within 30 days.

Outcomes reported are duration on ART in years from the time of enrolment to the last ART visit. We also report on EPLHIV's ART regimen, participant status (active in care, LTFU, deaths, transferred out/stopped) and HIV viral load (measured within one year) at time of last ART visit.

\section{What has been found?}

Figure 1 shows that a total of 101,652 NHGC participants $[$ APIN $=28,624 \quad(28 \%), \quad$ CCFNG $=10,481 \quad(10 \%)$, 
APIN, CCFNG, FHI 360 AND IHVN ARE THE FOUR MAJOR HIV PROGRAM IMPLEMENTERS IN NIGERIA

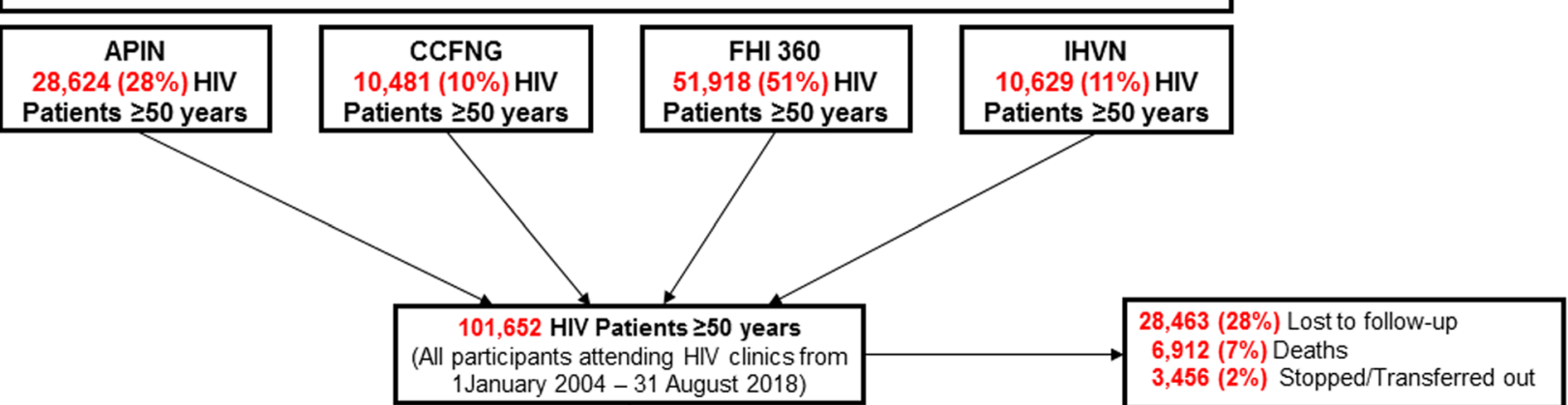

101,652 HIV Patients $\geq 50$ years

(Eligible for analysis)

Fig. 1 Study participants flowchart

FHI360 = 51,918 (51\%) and IHVN = 10,629 (11\%)] were enrolled for treatment at the health facilities supported by the IPs in 28 of the 36 States in Nigeria and the FCT, Abuja between 2004 and 2018. The NHGC includes approximately $36 \%$ of estimated EPLHIV in Nigeria.

The baseline characteristics of NHGC participants socio demographic and clinical findings are presented in Table 1. Median age was 57.1 (IQR 52-60 years); majority were women 53,608 (53\%) and married 51,037 (71\%). Participants data showed atleast secondary school education attendance by $31,280(52 \%)$ and unemployment in about 33,446 (51\%); most of the participants (73\%) commenced ART at WHO stage I/II; Median body mass index (BMI) at enrolment was $22.2 \mathrm{~kg} / \mathrm{m}^{2}$ (IQR 19.5$\left.25.4 \mathrm{~kg} / \mathrm{m}^{2}\right)$. 43,012 (55\%) had normal BMI $\left(18.5 \mathrm{~kg} / \mathrm{m}^{2}-\right.$ $\left.24.9 \mathrm{~kg} / \mathrm{m}^{2}\right)$, but 15,081 (19\%) were overweight with a BMI of $25-<30 \mathrm{~kg} / \mathrm{m}^{2}$ and a few were obese 6803 (9\%) with a BMI of $\geq 30 \mathrm{~kg} / \mathrm{m}^{2}$. Median systolic and diastolic blood measurements were $120 \mathrm{mmHg}$ (IQR 110-137 $\mathrm{mmHg}$ ) and $80 \mathrm{mmHg}$ (IQR $70-89 \mathrm{mmHg}$ ) respectively; $16,201(21 \%)$ of patients had hypertensive readings (systolic blood pressure $>140 \mathrm{mmHg}$ or diastolic blood pressure $>90 \mathrm{mmHg}$ ). Median CD4 count was 381 cells $/ \mu \mathrm{L}$ (IQR 212-577 cells $/ \mu \mathrm{L}$ ).

Table 2 present treatment outcomes of NHGC participants at their last visit. The median duration on ART treatment was 4.1 years (IQR 1.7-7.1 years); majority were on 1st line regimen at their last ART visit 97,586 (96\%) - the TDF based regimen had the highest number of patients 66,125 (65\%), consistent with the requirement of the treatment guidelines. Cohort's most patients (82.3\%) had viral suppression less than 1000 copies/ml within one year of their last visit. In terms of treatment outcome at their last visit, $62,821(62 \%)$ were active in treatment; 28,463 (28\%) lost to follow-up; 6912 (7\%) died, while on treatment and $3456(3 \%)$ had stopped or were transferred out.

\section{Discussions}

This study described the characteristics of EPLHIV in Nigeria; we found a lower prevalence of hypertension in older people on ART in Nigeria as compared to the prevalence of hypertension in sub-Saharan Africa $(31.9,95 \% \mathrm{CI}$ 18.5-49.2\%) and the global prevalence of hypertension (42.0, 95\%CI 29.0-55.4\%) [25]. Despite the relatively low prevalence of hypertension in older people living with HIV in Nigeria, it is very important for public health experts to deploy preventive interventions that will reduce the occurrence of hypertension. Also, government, HIV program implementers, donors and other HIV stakeholders should ensure that older people on ART who are living with high blood pressure should be able to receive care for hypertension when they visit HIV clinic. In addition, we observed that four out of five older people commenced on ART, were achieving viral suppression which is commendable. This estimate is very similar to the national prevalence of viral suppression among the total number of people placed on ART in Nigeria [26]. 
Table 1 Baseline characteristics of NHGC participants

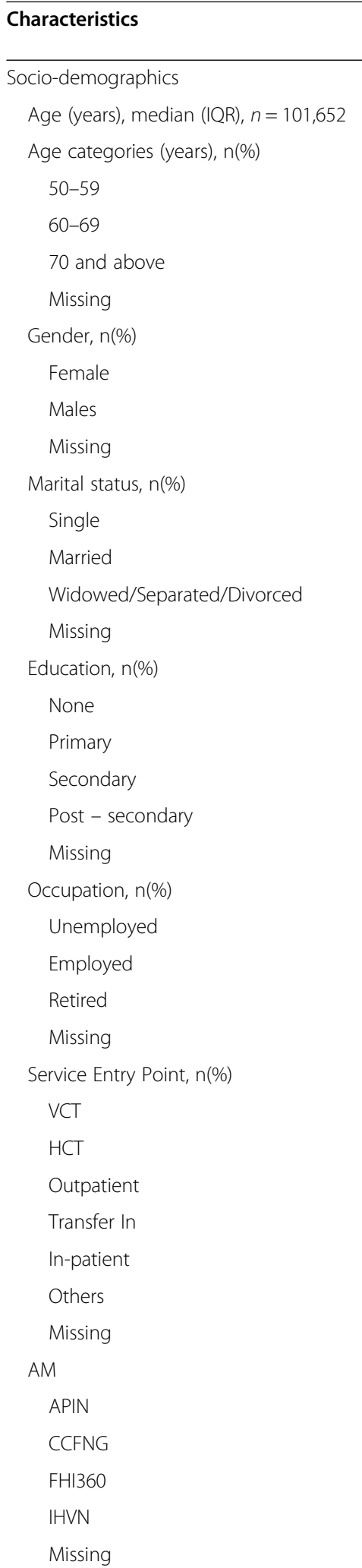

All participants

$N=101,652$

$57.1(52-60)$

$72,894(72 \%)$

$22,740(22 \%)$

$6018(6 \%)$

$0(0 \%)$

$53,608(53 \%)$

$48,044(47 \%)$

$0(0 \%)$

$3493(6 \%)$

$51,037(71 \%)$

$16,944(24 \%)$

$30,178(30 \%)$

$11,657(19 \%)$

$17,842(29 \%)$

$19,768(33 \%)$

$11,512(19 \%)$

$40,873(40 \%)$

$33,446(51 \%)$

$29,977(46 \%)$

$18,32(2.8 \%)$

$36,397(36 \%)$

$53,421(63 \%)$

$14,920(63 \%)$

$5227(22 \%)$

$1671(7 \%)$

$692(3 \%)$

$1337(6 \%)$

$24,384(24 \%)$

$28,624(28 \%)$

$10,481(10 \%)$

$51,918(51 \%)$

$10,629(11 \%)$

$0(0 \%)$
Table 1 Baseline characteristics of NHGC participants

(Continued)

\begin{tabular}{|c|c|}
\hline Characteristics & $\begin{array}{l}\text { All participants } \\
N=101,652\end{array}$ \\
\hline \multicolumn{2}{|l|}{ Clinical } \\
\hline \multicolumn{2}{|l|}{ WHO stage, $\mathrm{n}(\%)$} \\
\hline I & $26,617(47 \%)$ \\
\hline$\|$ & $14,500(26 \%)$ \\
\hline III & $13,728(24 \%)$ \\
\hline IV & $2102(4 \%)$ \\
\hline Missing & $44,705(44 \%)$ \\
\hline Weight, Kg, median (IQR), $n=79,912$ & $59(50-68)$ \\
\hline $\begin{array}{l}\text { Systolic Blood Pressure (SBP), } \\
\mathrm{mmHg} \text {, median (IQR), } n=76,421\end{array}$ & $120(110-137)$ \\
\hline $\begin{array}{l}\text { Diastolic Blood Pressure (DBP), } \\
\text { mmHg,median (IQR), } n=76,421\end{array}$ & $80(70-89)$ \\
\hline $\begin{array}{l}\text { Hypertension (SBP > 140/DBP } \\
>90 \mathrm{mmHg}, \mathrm{n}(\%), n=76,421\end{array}$ & $16,201(21 \%)$ \\
\hline $\begin{array}{l}\text { Body Mass Index, } \mathrm{Kg} / \mathrm{m}^{2} \text {, } \\
\text { median (IQR), } n=78,104\end{array}$ & $22.2(19.5-25.4)$ \\
\hline \multicolumn{2}{|l|}{ Body Mass Index, $\mathrm{Kg} / \mathrm{m}^{2}, \mathrm{n}(\%)$} \\
\hline$<17$ & $6240(8 \%)$ \\
\hline $17-<18.5$ & $6967(9 \%)$ \\
\hline $18.5-<25$ & $43,012(55 \%)$ \\
\hline $25-<30$ & $15,081(19 \%)$ \\
\hline 30 and above & $6803(9 \%)$ \\
\hline Missing & $23,548(23 \%)$ \\
\hline 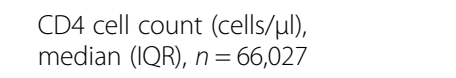 & $381(212-577)$ \\
\hline $\begin{array}{l}\text { CD4 cell count }<200 \\
\text { cells } / \mu l, n(\%), n=66,027\end{array}$ & $15,325(23 \%)$ \\
\hline $\begin{array}{l}\text { CD4 cell count }<500 \\
\text { cells } / \mu \mathrm{l}, \mathrm{n}(\%), n=66,027\end{array}$ & $43,783(66 \%)$ \\
\hline
\end{tabular}

Results are number and column \% of those with non-missing data; missing data rows are number and column $\%$ of missing data

IQR Interquartile range, ART Antiretroviral Therapy, APIN APIN Public Health Initiative in Nigeria, CCFNG Catholic Caritas Foundation of Nigeria, IHVN Institute of Human Virology Nigeria

Results are number (column percentage of those with non-missing data) for categorical variables and median (interquartile range) for continuous variables

Our finding is consistent with the regional prevalence of viral suppression among people on ART in West and Central Africa region [27] but lower than the observed prevalence in East and Southern Africa region [28]. However, despite the high prevalence of viral suppression among patients on ART in Nigeria, including most African countries, more effort should be geared towards improving HIV identification as less than two-thirds of this populations are aware of their HIV status [26].

\section{Future plans?}

The NHGC is the largest cohort of EPLHIV in Nigeria; it provides a strong base for future studies on 
Table 2 Outcomes of NHGC participants at last clinic visit

\begin{tabular}{|c|c|}
\hline Outcome & $\begin{array}{l}\text { All participa } \\
\mathrm{N}=101,652\end{array}$ \\
\hline \multicolumn{2}{|l|}{ ART Regimen } \\
\hline \multicolumn{2}{|l|}{ ART regimen line at last visit, n(\%) } \\
\hline First line & $97,586(96 \%)$ \\
\hline Second Line & $4066(4 \%)$ \\
\hline \multicolumn{2}{|l|}{ Current ART regimen at last visit, $\mathrm{n}(\%)$} \\
\hline ABC-Based & $3050(3 \%)$ \\
\hline AZT-Based & $29,479(29 \%)$ \\
\hline TDF-Based & $66,125(65 \%)$ \\
\hline Others & $2998(3 \%)$ \\
\hline Number of years on ART treatment, median (IQR) & $4.1(1.7-7.1)$ \\
\hline \multicolumn{2}{|l|}{ Number of years on ART treatment, $n(\%)$} \\
\hline$<2$ & $29,225(29 \%)$ \\
\hline $2-<5$ & $31,095(31 \%)$ \\
\hline $5-<10$ & $31,512(32 \%)$ \\
\hline 10 and above & $9819(10 \%)$ \\
\hline \multicolumn{2}{|l|}{ Viral Load ${ }^{a}$} \\
\hline \multicolumn{2}{|l|}{ Viral load at last measurement, copies/ml, n(\%) } \\
\hline$<1000$ & $26,687(82 \%)$ \\
\hline \multicolumn{2}{|l|}{ Participant status } \\
\hline \multicolumn{2}{|l|}{ Status at last visit, $\mathrm{n}(\%)$} \\
\hline Active in care & $62,821(62 \%)$ \\
\hline Died & $6912(7 \%)$ \\
\hline Lost to follow-up & $28,463(28 \%)$ \\
\hline Stopped/Transferred Out & $3456(3 \%)$ \\
\hline
\end{tabular}

Results are number and percent of those with non-missing data; ${ }^{a}$ Only 38,199 (38\%) had a viral measurement within one year of their last visit ART Antiretroviral Therapy, ABC Abacavir, AZT Zidovudine, TDF Tenofovir Disoproxil Fumarate

comorbidities associated with aging in EPLHIV in the country. We plan to follow up this cohort and obtain data that would be used to implement intervention programs, develop prognostic models and predict better outcomes for EPLHIV using multi-variable indices.

\section{What are the main strengths and weaknesses?}

A large pool of geriatric patients and the collaborating spirit of the IPs contributing data to this cohort is a key strength for the NHGC. The substantial dataset of the NGHC permits examination of prognoses in improving the quality of life of EPLHIV. Data of patients in this cohort are collected during routine clinical visits, and incomplete data from missing variables exist. Data on AIDS- mortality is likely under-reported as ART clients that died outside hospital settings may never have this status reverted to their service provider except following active tracking. Furthermore, public mortality repositories in Nigeria do not usually share information with hospitals and clinical autopsies are not mainstream $[29,30]$.

Another expected limitation of a longitudinal cohort study is loss to follow-up, a particularly challenging norm in low income settings where participants have a poor history of follow-up in clinical care. To improve patient's retention in our cohort, we developed a monitoring and tracking system to identify patients that are due for follow up visits. These patients are called using registered anonymous public health lines and sent cyphered short message service prompts to remind them of their clinic visits. We also deployed community engagement strategies and care group network to keep the patients engaged in care.

\section{Conclusion}

The NHGC represents about $36 \%$ of the total estimates and is the largest cohort of EPLHIV in Nigeria. It provides a strong basis for studies on comorbidities associated with aging in EPLHIV in the country. Longitudinal monitoring of this cohort could be used to design and implement intervention programs, develop prognostic models and achieve better care outcomes for EPLHIV.

\section{Abbreviations \\ HIV: Human immunodeficiency virus; ART: Antiretroviral therapy; AIDS: Acquired immune deficiency syndrome; NAllS: Nigeria HIV/AIDS indicator and impact survey; ARV: Antiretroviral; Ols: Opportunistic infections; IM: Myocardial infarction; MSF: Médecins Sans Frontières; NACA: National Agency for the Control of AIDS; FMOH: Federal Ministry of Health; USG: United States of America's Government; PEPFAR: its Presidents Emergency Plan for AIDS Relief; IPs: Implementing partners; IHVN: Institute of Human Virology Nigeria; FCT: Federal Capital Territory; APIN: Public Health Initiative in Nigeria; CCFNG: Catholic Caritas Foundation of Nigeria; CDC: Centers for Disease Control and Prevention; USAID: United States Agency for International Development; DoD: Department of Defense; PLHIV: People living with HIV; CRFs: Case Report Forms; VL: Viral load; DTG: Dolutegravir; BMI: Body mass index; IQR: Interquantile range; EPLHIV: Elderly people living with HIV; NHGC: Nigerian HIV Geriatric Cohort.}

\section{Acknowledgements}

The NHGC is not possible without the ongoing contribution of all ART focal persons and clinic managers, pharmacists and staff at the diagnostic laboratories and facilities in the HIV treatment facilities. We also acknowledge the work of the data collecting and monitoring staff working with the collaborating IPs. We are grateful to all participants of NHGC.

\section{Authors' contributions}

PD conceived the idea and all authors (PD MKO, JO, YKA, GAK, IEN, NN, CM, $\mathrm{HK}, \mathrm{PO}, \mathrm{JOO}$ and $\mathrm{EE}$ ) contributed to the study design, data generation and data review. MKO, JO, YKA, and GAK analysed the data. PD wrote the first draft and all authors critically reviewed and contributed to the drafting of the manuscript. All authors have read and approved the manuscript.

\section{Funding}

No funding was received to conduct this study.

\section{Availability of data and materials}

The chief investigator of the study is Patrick Dakum, whose e-mail contact is (pdakum@ihvnigeria.org). The data remains the property of the contributing NISA member organizations, whose representatives manage the NHGC via a steering committee of the collaboration. Inquiries on the use of collected data are welcomed and encouraged and all proposals for specific analyses 
are to be reviewed by a scientific committee. The datasets are available from the first author on reasonable request.

\section{Ethics approval and consent to participate}

Ethical clearance for the use of the secondary data was obtained from the IRB board (IRB019 SD) of AIDS Prevention Initiative in Nigeria (APIN - https:// apin.org.ng/about-us/)

\section{Consent for publication}

Not applicable.

\section{Competing interests}

We declare no competing interests and state no conflicts of Interest.

\section{Author details}

${ }^{1}$ Institute of Human Virology, Abuja, Nigeria. ${ }^{2}$ FHI360, Abuja, Nigeria. ${ }^{3}$ APIN Public Health Initiatives, Ltd/Gte, Abuja, Nigeria. ${ }^{4}$ Catholic Caritas Foundation of Nigeria, Abuja, Nigeria. ${ }^{5}$ Nigeria Implementation Science Alliance, Abuja, Nigeria. ${ }^{6}$ Department of Paediatrics and Child health, University of Nigeria, Enugu, Nigeria.

\section{Received: 3 December 2019 Accepted: 4 November 2020}

\section{Published online: 26 November 2020}

\section{References}

1. Manfredi R. HIV infection and advanced age emerging epidemiological, clinical, and management issues. Ageing Res Rev. 2004;3:31-54. https://doi. org/10.1016/j.arr.2003.07.001.

2. Inelman EM, Gasparini G, Enzi G. HIV/AIDS in older adults: a case report and literature review. Geriatrics. 2005;60:26-30.

3. Albone R. Older people remain invisible in the response to HIV and AIDS. In: HelpAge International [Internet]. [cited 13 May 2020]. Available: https:// www.helpage.org/blogs/rachel-albone-667/older-people-remain-invisible-inthe-response-to-hiv-and-aids-201/

4. Autenrieth CS, Beck EJ, Stelzle D, Mallouris C, Mahy M, Ghys P. Global and regional trends of people living with HIV aged 50 and over: estimates and projections for 2000-2020. PLoS One. 2018;13. https://doi.org/10.1371/ journal.pone.0207005.

5. Negin J. Cumming RG. HIV infection in older adults in sub-Saharan Africa: extrapolating prevalence from existing data. Bull World Health Organ. 2010; 88:847-53. https://doi.org/10.2471/BLT.10.076349.

6. Negin J, Mills EJ, Bärnighausen T. Aging with HIV in Africa: the challenges of living longer. AIDS Lond Engl. 2012;26:S1-5. https://doi.org/10.1097/QAD. Ob013e3283560f54.

7. Avong YK, van Wyk B, Njab J, Abimiku AG, Ndembi N, Okuma J, et al. Adherence to anti-retroviral therapy in north Central Nigeria. Curr HIV Res. 2015;13:268-78. https://doi.org/10.2174/1570162x13666150202094120.

8. Federal Ministry of Health Nigeria. National Guidelines for HIV Prevention Treatment and Care, Abuja. Available: http://apps.who.int/medicinedocs/ documents/s23252en/s23252en.pdf. Accessed 15 June 2019.

9. National Agency for the Control of AIDS Nigeria. Revised National Hiv and Aids Strategic Framework. Nigeria; Available: https://naca.gov.ng/wpcontent/uploads/2019/03/NATIONAL-HIV-AND-AIDS-STRATEGICFRAMEWORK-1.pdf. Accessed 15 June 2019.

10. UNAIDS. 90-90-90 - An ambitious treatment target to help end the AIDS epidemic. Available: https://www.unaids.org/sites/default/files/media_asset/ 90-90-90_en_0.pdf. Accessed 15 June 2019.

11. USAID. Children on the Brink 2002: A Joint Report on Orphan Estimates and Program Strategies. Available: http://data.unaids.org/topics/youngpeople/childrenonthebrink_en.pdf.

12. Lekalakala-Mokgele E. A literature review of the impact of HIV and AIDS on the role of the elderly in the sub-Saharan African community. Health SA Gesondheid Online. 2011;16:1-6.

13. Hontelez JAC, de Vlas SJ, Baltussen R, Newell M-L, Bakker R, Tanser F, et al. The impact of antiretroviral treatment on the age composition of the HIV epidemic in sub-Saharan Africa. AIDS Lond Engl. 2012;26(Suppl 1):S19-30. https://doi.org/10.1097/QAD.0b013e3283558526.

14. Hommes MJ, Romijn JA, Endert E, Eeftinck Schattenkerk JK Sauerwein HP. Insulin sensitivity and insulin clearance in human immunodeficiency virusinfected men. Metabolism. 1991;40:651-6. https://doi.org/10.1016/00260495(91)90059-6.
15. Hadigan C, Miller K, Corcoran C, Anderson E, Basgoz N, Grinspoon S. Fasting hyperinsulinemia and changes in regional body composition in human immunodeficiency virus-infected women. J Clin Endocrinol Metab. 1999;84: 1932-7. https://doi.org/10.1210/jcem.84.6.5738.

16. Behrens G, Dejam A, Schmidt H, Balks HJ, Brabant G, Körner T, et al. Impaired glucose tolerance, beta cell function and lipid metabolism in HIV patients under treatment with protease inhibitors. AIDS Lond Engl. 1999;13: F63-70. https://doi.org/10.1097/00002030-199907090-00001.

17. Brown TT, Cole SR, Li X, Kingsley LA, Palella FJ, Riddler SA, et al. Antiretroviral therapy and the prevalence and incidence of diabetes mellitus in the multicenter AIDS cohort study. Arch Intern Med. 2005;165:1179-84. https://doi.org/10.1001/archinte.165.10.1179.

18. Gebo KA, Justice A. HIV infection in the elderly. Curr Infect Dis Rep. 2009;11: 246-54. https://doi.org/10.1007/s11908-009-0036-0.

19. Sefasi AP. Impact of HIV and AIDS on the eldery: a case study of Chiladzulu district. Malawi Med J J Med Assoc Malawi. 2010;22:101-3.

20. Buckley S. AIDS in Kenya:Wife Inheritance Spurs AIDS Rise in Kenya. [cited 13 May 2020]. Available: https://www.washingtonpost.com/wp-srv/inatl/ longterm/africanlives/kenya/kenya_aids.htm.

21. Williams A, Tumwekwase G. We will be alone when we die: HIV/AIDS and the aged in rural Uganda; 1999.

22. United Nations Department of Economic and Social Affairs/Population Division. The Impact of AIDS. New York, United States; Available: https:// www.un.org/en/development/desa/population/publications/hiv-aids/aidsimpact.asp. Accessed 15 June 2019.

23. WHO. Good health adds life to years. In: WHO [Internet]. World Health Organization; [cited 13 May 2020]. Available: http://www.who.int/ageing/ publications/whd2012_global_brief/en/. Accessed 15 June 2019.

24. WHO. Nigeria: Country profile. In: WHO [Internet]. World Health Organization; [cited 13 May 2020]. Available: http://www.who.int/countries/ nga/en/.

25. Dakum P, Kayode GA, Abimiku A, Avong YK, Okuma J, Onyemata E, et al. Prevalence of hypertension among patients aged 50 and older living with human immunodeficiency virus. Medicine (Baltimore). 2019;98. https://doi. org/10.1097/MD.0000000000015024.

26. HIV and AIDS in Nigeria. [cited 13 May 2020]. Available: https://www.avert. org/professionals/hiv-around-world/sub-saharan-africa/nigeria.

27. HIV and AIDS in West and Central Africa. [cited 13 May 2020]. Available: https://www.avert.org/hiv-and-aids-west-and-central-africa.

28. HIV and AIDS in East and Southern Africa Regional Overview. [cited 13 May 2020]. Available: https://www.avert.org/professionals/hiv-around-world/subsaharan-africa/overview.

29. Oluwasola OA, Fawole OI, Otegbayo AJ, Ogun GO, Adebamowo CA, Bamigboye AE. The autopsy: knowledge, attitude, and perceptions of doctors and relatives of the deceased. Arch Pathol Lab Med. 2009;133:7882. https://doi.org/10.1043/1543-2165-133.1.78.

30. Oluwasola AO, Fawole OI, Otegbayo JA, Ayede IA, Ogun GO, Ukah CO, et al. Trends in clinical autopsy rate in a Nigerian tertiary hospital. Afr J Med Med Sci. 2007;36:267-72.

\section{Publisher's Note}

Springer Nature remains neutral with regard to jurisdictional claims in published maps and institutional affiliations.

Ready to submit your research? Choose BMC and benefit from

- fast, convenient online submission

- thorough peer review by experienced researchers in your field

- rapid publication on acceptance

- support for research data, including large and complex data types

- gold Open Access which fosters wider collaboration and increased citations

- maximum visibility for your research: over $100 \mathrm{M}$ website views per year

At $\mathrm{BMC}$, research is always in progress.

Learn more biomedcentral.com/submissions 